\title{
PCM1/RET Fusion Protein
}

National Cancer Institute

\section{Source}

National Cancer Institute. PCM1/RET Fusion Protein. NCI Thesaurus. Code C99400.

A fusion protein encoded by the PCM1/RET fusion gene. This protein is comprised of approximately $1600 \mathrm{~N}$-terminal amino acids from the pericentriolar material 1 protein fused to almost the entire C-terminal cytoplasmic domain of the proto-oncogene tyrosine-protein kinase receptor Ret protein, including the tyrosine kinase domain. 